\title{
Palladium Promoted Production of Higher Amines from a Lower Amine Feedstock
}

\author{
Yufen Hao $^{1} \cdot$ Fernando Cárdenas-Lizana $^{1} \cdot$ Mark A. Keane $^{1}$
}

Received: 15 September 2016 / Accepted: 27 October 2016 / Published online: 14 February 2017

(C) The Author(s) 2016. This article is published with open access at Springerlink.com

\begin{abstract}
The catalytic $\left(\mathrm{Pd} / \mathrm{Al}_{2} \mathrm{O}_{3}\right.$ and $\mathrm{Pd} / \mathrm{C}$; mean $\mathrm{Pd}$ size 2.5-3.0 nm from (S)TEM analysis) synthesis of dibutylamine (DBA) and tri-butylamine (TBA) from monobutylamine (MBA) and DBA, respectively, in continuous gas phase operation is demonstrated. Exclusive production of DBA (from MBA) has been established over both catalysts where $453 \leq T \leq 523 \mathrm{~K}\left(\Delta \mathrm{E}_{\mathrm{a}}=79 \mathrm{~kJ} \mathrm{~mol}^{-1}\right)$. Greater
\end{abstract}

activity for $\mathrm{Pd} / \mathrm{C}$ is associated with higher levels of surface acidity (from $\mathrm{NH}_{3}$ chemisorption/TPD) and spillover hydrogen (from $\mathrm{H}_{2}$ TPD). Reaction of DBA over both catalysts when configured in series delivered full selectivity to TBA. Our results establish a novel clean alternative route for the continuous production of higher (secondary and tertiary) amines.

\section{Graphical Abstract}

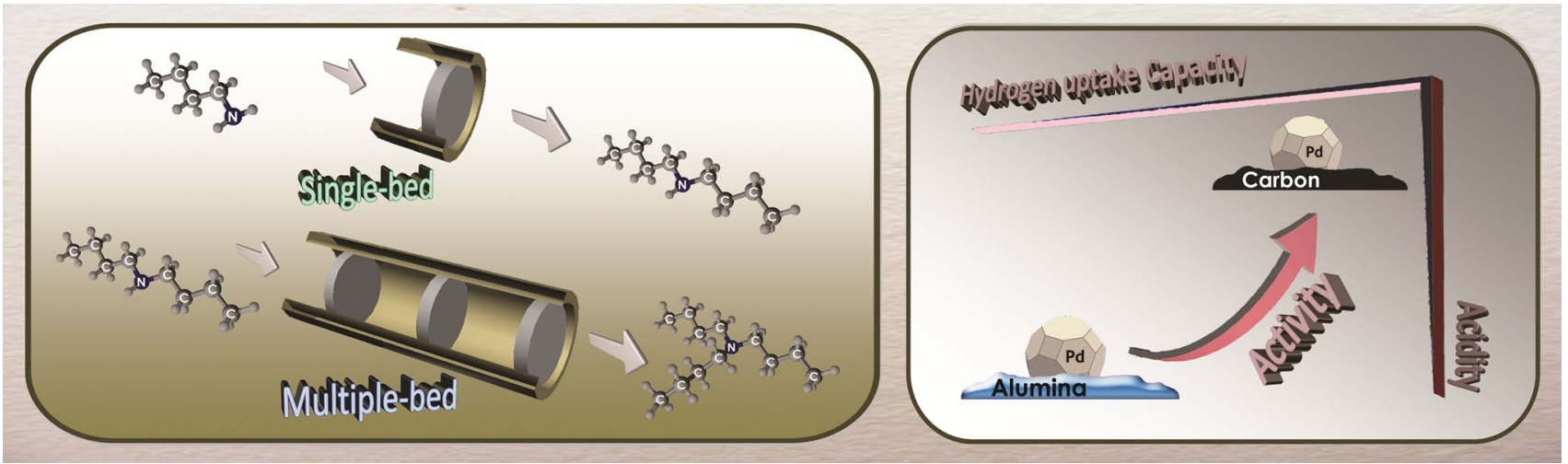

Keywords Secondary amine $\cdot$ Tertiary amine $\cdot \mathrm{Pd} /$ $\mathrm{Al}_{2} \mathrm{O}_{3} \cdot \mathrm{Pd} / \mathrm{C} \cdot$ Catalyst beds in series

Mark A. Keane

M.A.Keane@hw.ac.uk

Yufen Hao

Y.Hao@hw.ac.uk

Fernando Cárdenas-Lizana

F.CardenasLizana@hw.ac.uk

1 Chemical Engineering, School of Engineering and Physical Sciences, Heriot-Watt University, Edinburgh EH14 4AS, Scotland, UK

\section{Introduction}

Higher (secondary and tertiary) amines are commercially important in the production of a range of chemical products [1, 2] used in drug production [3] and as solvents in extraction processes [2]. Standard synthesis involves (i) $\mathrm{N}$-alkylation of primary amines with alkyl halides or alcohols [1, 4, 5], (ii) reduction of imines 
using reducing agents (e.g. $\mathrm{NaCNBH}_{3}$ ) in liquid batch mode [3] or hydrogenation of nitriles over supported Pt $[6,7]$ and Pd [8]. These methods are non-selective and produce amine mixtures. Moreover, they use toxic agents and require complex extraction of the target product with multiple separation/purification steps. Conversion of an amine feedstock to a higher amine product has been considered to a limited extent in the literature and the reaction mechanism is poorly understood. Taking mono-butylamine (MBA) as a model reactant (Fig. 1), dehydrogenation (step 1) generates a reactive butylidenimine (BI) intermediate, which readily reacts with MBA (step 2) to form $N$-butylidene-butylamine (BBA) with the elimination of $1 \mathrm{~mol} \mathrm{NH}_{3}$. BBA can be hydrogenated (step 3) to di-butylamine (DBA). Tertiary amine synthesis from secondary amines has only been reported by homogeneous catalysis $\left[\mathrm{RuCl}_{3} \cdot \mathrm{xH}_{2} \mathrm{O}\right.$ and $\left.\mathrm{P}\left(\mathrm{C}_{6} \mathrm{H}_{5}\right)\right]$ in one patent [9] and we could not find any published reaction mechanism for di-amine to tri-amine transformation. The limited reports on primary amine condensation have employed homogenous catalysts [3, 10-14] that are difficult to recover and reuse. An efficient amine condensation system utilising reusable heterogeneous catalysts in continuous mode at ambient pressure as proposed in this work represents a significant advancement in terms of cleaner processing.

Work to date on the condensation of primary amines over heterogeneous systems suffers from data irreproducibility in terms of temperature control associated with microwave irradiation (of MBA over $\mathrm{Pt} / \mathrm{C}$ mixed with alumina powder [15]) and the formation of significant amounts of undesired imine by-product (over $\mathrm{Cu} / \mathrm{Al}_{2} \mathrm{O}_{3}$ [16] and Pt/C [10]). Given the established performance of Pd catalysts in dehydrogenation [17-19] and hydrogenation [20-22], critical steps in higher amine synthesis (see Fig. 1), we have adopted $\mathrm{Pd} / \mathrm{C}$ and $\mathrm{Pd} / \mathrm{Al}_{2} \mathrm{O}_{3}$ as suitable catalyst candidates for this process. Activated carbon [23, 24] and alumina [25-27] supports bear acid sites that favour condensation to generate higher amines $[28,29]$, as has been shown for acid catalysts (e.g. K-10 montmorillonite [30, 31]). Moreover, electron transfer between the carrier and Pd phase can influence reactant activation and impact on catalytic performance [32] but this effect has not been considered in higher amine production. In this study, we evaluate the feasibility of secondary and tertiary amine production from lower amines in continuous gas phase operation. We compare the catalytic action of $\mathrm{Pd} / \mathrm{C}$ and $\mathrm{Pd} / \mathrm{Al}_{2} \mathrm{O}_{3}$ and propose a reaction mechanism based on our results. We demonstrate that the use of catalyst beds in series facilitates full selectivity to the higher amine at elevated rates.
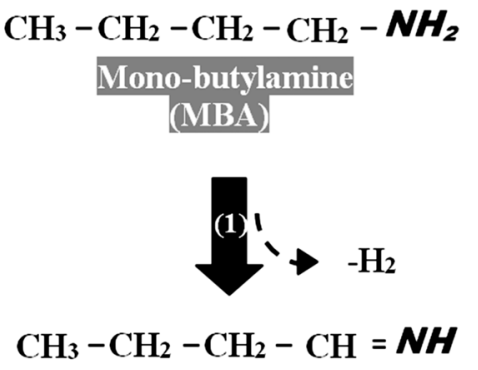

Butylidenimine

(BI)

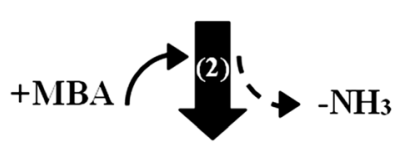

$\mathrm{CH}_{3}-\mathrm{CH}_{2}-\mathrm{CH}_{2}-\mathrm{CH}=\mathrm{N}-\mathrm{CH}_{2}-\mathrm{CH}_{2}-\mathrm{CH}_{2}-\mathrm{CH}_{3}$
N-Butylidene-butylamine

(BBA)

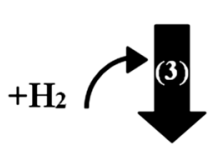

$\mathrm{CH}_{3}-\mathrm{CH}_{2}-\mathrm{CH}_{2}-\mathrm{CH}_{2}-\mathrm{NH}-\mathrm{CH}_{2}-\mathrm{CH}_{2}-\mathrm{CH}_{2}-\mathrm{CH}_{3}$
Di-butylamine
(DBA)

Fig. 1 Schematic showing the reaction pathways associated with the conversion of mono-butylamine (MBA) to di-butylamine (DBA)

\section{Experimental}

\subsection{Catalyst Characterisation}

Commercial ( $1 \%$ w/w) $\mathrm{Pd} / \mathrm{C}$ and $\mathrm{Pd} / \mathrm{Al}_{2} \mathrm{O}_{3}$ catalysts were obtained from Sigma-Aldrich. The Pd content was measured by inductively coupled plasma-optical emission spectrometry (ICP-OES, Vista-PRO, Varian Inc.) from the diluted extract in HF. Catalyst activation by temperature programmed reduction (TPR), $\mathrm{H}_{2}$ and $\mathrm{NH}_{3}$ chemisorption, temperature programmed desorption (TPD) and specific surface area (SSA) measurements were carried out in the CHEM-BET 3000 (Quantachrome) unit equipped with a thermal conductivity detector (TCD) for continuous monitoring of gas composition and the TPR Win ${ }^{\mathrm{TM}}$ software for data acquisition/manipulation. Samples $(0.05-0.1 \mathrm{~g})$ were loaded in a U-shaped Quartz cell (3.76 mm i.d.), outgassed for $30 \mathrm{~min}$ and the total SSA recorded in a $30 \% \mathrm{v} / \mathrm{v} \mathrm{N}_{2} / \mathrm{He}$ flow with undiluted $\mathrm{N}_{2}$ (BOC, 99.9\%) as internal standard. Two cycles of $\mathrm{N}_{2}$ adsorption-desorption were employed using the standard single point BET method. TPR was conducted in $17 \mathrm{~cm}^{3} \mathrm{~min}^{-1}$ (Brooks mass flow controlled) 
$5 \% \mathrm{v} / \mathrm{v} \mathrm{H}_{2} / \mathrm{N}_{2}$ at $2 \mathrm{~K} \mathrm{~min}^{-1}$ to $573 \mathrm{~K}$ [32]. Samples were swept with $65 \mathrm{~cm}^{3} \mathrm{~min}^{-1} \mathrm{~N}_{2}$ for $1.5 \mathrm{~h}$, cooled to ambient temperature and subjected to $\mathrm{H}_{2}$ (BOC, $\left.99.99 \%\right)$ or $\mathrm{NH}_{3}$ (BOC, 99.98\%) pulse $(50-1000 \mu \mathrm{l})$ titration. The samples were thoroughly flushed in $\mathrm{N}_{2} / \mathrm{He}\left(65 \mathrm{~cm}^{3} \mathrm{~min}^{-1}\right)$ to remove weakly bound $\mathrm{H}_{2}$ or $\mathrm{NH}_{3}$ and subjected to TPD at $10-50 \mathrm{~K} \mathrm{~min}^{-1}$ (in $65 \mathrm{~cm}^{3} \mathrm{~min}^{-1} \mathrm{~N}_{2}$ ) to $950-1200 \mathrm{~K}$. SSA and $\mathrm{H}_{2} / \mathrm{NH}_{3}$ uptake/release values were reproducible to within $\pm 5 \%$ and the values quoted represent the mean. Palladium particle morphology (size and shape) was determined by transmission (JEOL JEM 2011 TEM unit) and scanning transmission (JEOL 2200FS field emission gunequipped TEM unit) electron microscopy, employing Gatan DigitalMicrograph 1.82 for data acquisition/manipulation. Samples for analysis were crushed and deposited (dry) on a holey carbon/Cu grid (300 Mesh). Up to 800 individual Pd particles were counted for each catalyst and the surface area-weighted metal diameter $\left(d_{(\mathrm{S}) \mathrm{TEM}}\right)$ calculated from

$d_{\text {(S)TEM }}=\frac{\sum_{\mathrm{i}} n_{\mathrm{i}} d_{\mathrm{i}}^{3}}{\sum_{\mathrm{i}} n_{\mathrm{i}} d_{\mathrm{i}}^{2}}$

where $n_{\mathrm{i}}$ is the number of particles of diameter $d_{\mathrm{i}}$. X-ray photoelectron spectroscopy (XPS) analyses were conducted on an Axis Ultra instrument (Kratos Analytical) under ultra-high vacuum conditions $\left(<10^{-8}\right.$ Torr) using a monochromatic Al $\mathrm{K} \alpha$ X-ray source $(1486.6 \mathrm{eV})$. The source power was maintained at $150 \mathrm{~W}$ and the emitted photoelectrons were sampled from a $750 \times 350 \mu \mathrm{m}^{2}$ area at a take-off angle $=90^{\circ}$. The analyser pass energy was $80 \mathrm{eV}$ for survey spectra $(0-1000 \mathrm{eV})$ and $40 \mathrm{eV}$ for high resolution spectra $\left(\operatorname{Pd} 3 d_{5 / 2}\right.$ and $\left.3 d_{3 / 2}\right)$. The adventitious carbon $1 s$ peak was calibrated at $284.5 \mathrm{eV}$ and used as an internal standard to compensate for charging effects.

\subsection{Catalytic Procedure}

Reactions (of MBA and DBA, Sigma-Aldrich, $\geq 99 \%$ ) were conducted in situ, immediately after catalyst activation, under atmospheric pressure over the temperature range $453-523 \mathrm{~K}$ in a fixed bed vertical glass reactor (i.d. $=15 \mathrm{~mm}$ ). The reactant was delivered at a fixed calibrated flow rate to the reactor via a glass/Teflon air-tight syringe and Teflon line using a microprocessor controlled infusion pump (Model $100 \mathrm{kd} \mathrm{Scientific).} \mathrm{A} \mathrm{layer} \mathrm{of} \mathrm{borosili-}$ cate glass beads served as preheating zone, ensuring the reactants were vaporised and reached reaction temperature before contacting the catalyst bed. Isothermal conditions $( \pm 1 \mathrm{~K})$ were maintained by diluting the catalyst bed with ground glass $(75 \mu \mathrm{m})$; the ground glass was mixed thoroughly with catalyst before insertion in the reactor. Reaction temperature was continuously monitored using a thermocouple inserted in a thermowell within the catalyst bed.
A co-current flow of amine and ultra pure (BOC, $>99.99 \%$ ) $\mathrm{H}_{2}$ was maintained at total $G H S V=1 \times 10^{4} \mathrm{~h}^{-1}$ with an inlet amine molar flow $(F)$ of $3.5-6.1 \mathrm{mmol} \mathrm{h}^{-1}$. The $\mathrm{H}_{2}$ flow rate was monitored using a Humonics (Model 520) digital flowmeter. The molar Pd $(n)$ to $F$ ratio spanned the range $0.3 \times 10^{-3}$ to $2.5 \times 10^{-3} \mathrm{~h}$. In blank tests, passage of MBA or DBA in a stream of $\mathrm{H}_{2}$ through the empty reactor did not result in any detectable conversion. The reactor effluent was frozen in a liquid $\mathrm{N}_{2}$ trap for subsequent analysis by capillary GC (Perkin-Elmer Auto System XL chromatograph equipped with a programmed split/splitless injector and FID), employing a DB- 1 capillary column (i.d. $=0.33 \mathrm{~mm}$, length $=50 \mathrm{~m}$, film thickness $=0.20 \mu \mathrm{m}$ ). The effluent gas from the DBA reaction was bubbled through a water trap to absorb $\mathrm{NH}_{3}$ at ambient temperature [33]; $\mathrm{pH}$ was monitored ( $\mathrm{pH}$ meter, Hanna Instruments) with time on-stream [34]. Reactant/product molar fractions $\left(x_{\mathrm{i}}\right)$ were obtained using detailed calibration plots (not shown). Fractional conversion $(X)$ is given by

$X(-)=\frac{[\text { reactant }]_{\text {in }}-[\text { reactant }]_{\text {out }}}{[\text { reactant }]_{\text {in }}}$

with product selectivity $\left(S_{\mathrm{i}}\right)$

$S_{\mathrm{i}}(\%)=\frac{N_{\mathrm{i}} \cdot x_{\mathrm{i}}}{\sum N_{\mathrm{i}} \cdot x_{\mathrm{i}}} \times 100$

where $[\text { reactant }]_{\text {in }}$ and $[\text { reactant }]_{\text {out }}$ represent the concentration of amine entering (in) and leaving (out) the reactor and $N_{\mathrm{i}}$ is the stoichiometric coefficient for each product. Reactant consumption rate $(R)$ was obtained from

$R\left(\mathrm{~mol}_{\text {reactant }} \mathrm{h}^{-1} \mathrm{~mol}_{\mathrm{Pd}}^{-1}\right)=\frac{X \times F}{n}$

Repeated reactions with different samples from the same batch of catalyst delivered raw data reproducibility and mass balances to within $\pm 6 \%$.

\section{Results and Discussion}

\subsection{Production of DBA from MBA}

The existing literature suggests that formation of secondary amines from the corresponding mono-amine is a multi-step process (see Fig. 1), involving dehydrogenation (MBA $\rightarrow \mathrm{BI}$, step 1), condensation with $\mathrm{NH}_{3}$ release $(\mathrm{BI}+\mathrm{MBA} \rightarrow \mathrm{BBA}$, step 2) and hydrogenation $(\mathrm{BBA} \rightarrow \mathrm{DBA}$, step 3) [10]. Reaction over $\mathrm{Pd} / \mathrm{C}$ and $\mathrm{Pd} /$ $\mathrm{Al}_{2} \mathrm{O}_{3}$ resulted in the sole formation of DBA from MBA. In contrast, Kamiguchi and co-workers [10], using $\mathrm{Pd} / \mathrm{C}$ to promote the gas phase condensation of MBA over 573-773 K, obtained BBA as principal and DBA as secondary product $\left(S_{\mathrm{DBA}}<13 \%\right)$. High temperatures favour 
desorption of BBA [35] and the exclusivity to DBA that we achieve can be tentatively linked to the lower reaction temperature that allows transformation of BBA without desorption. In terms of catalytic activity, $\mathrm{Pd} / \mathrm{C}(208$ $\mathrm{mol}_{\mathrm{MBA}} \mathrm{h}^{-1} \mathrm{~mol}_{\mathrm{Pd}}{ }^{-1}$ ) delivered a greater MBA transformation rate than $\mathrm{Pd} / \mathrm{Al}_{2} \mathrm{O}_{3}\left(154 \mathrm{~mol}_{\mathrm{MBA}} \mathrm{h}^{-1} \mathrm{~mol}_{\mathrm{Pd}}{ }^{-1}\right)$. There is evidence in the literature that catalytic activity in hydrogenation [36] and dehydrogenation [37], critical for DBA generation (Fig. 1), is influenced by variations in Pd dispersion. The STEM/TEM images provided in Fig. 2, II) for $\mathrm{Pd} / \mathrm{C}$ (Fig. 2A) and $\mathrm{Pd} / \mathrm{Al}_{2} \mathrm{O}_{3}$ (Fig. 2B) reveal quasi-spherical particles at the nano-scale with a narrow
(1-6 nm) size distribution (Fig. 2, III) and an equivalent mean (2.5-3.0 nm, Table 1). The observed differences in reaction rate can not be explained by variations in $\mathrm{Pd}$ size. In prior work [38], we demonstrated that condensation reactions in the conversion of butyronitrile to amines is enhanced by support acidity as has been noted for activated carbon [23, 24] and alumina [25-27]. Ambient temperature $\mathrm{NH}_{3}$ chemisorption coupled with TPD was used to quantify surface acidity. Ammonia release from $\mathrm{Pd} / \mathrm{C}$ by TPD matched that chemisorbed and exceeded the amount recorded for $\mathrm{Pd} / \mathrm{Al}_{2} \mathrm{O}_{3}$ (Table 1). Increased surface acidity facilitates condensation (Fig. 1, step 2),
Fig. 2 Representative (I) medium and (II) high magnification TEM/STEM images with (III) associated Pd size distribution for (A) $\mathrm{Pd} / \mathrm{C}$ and (B) $\mathrm{Pd} / \mathrm{Al}_{2} \mathrm{O}_{3}$
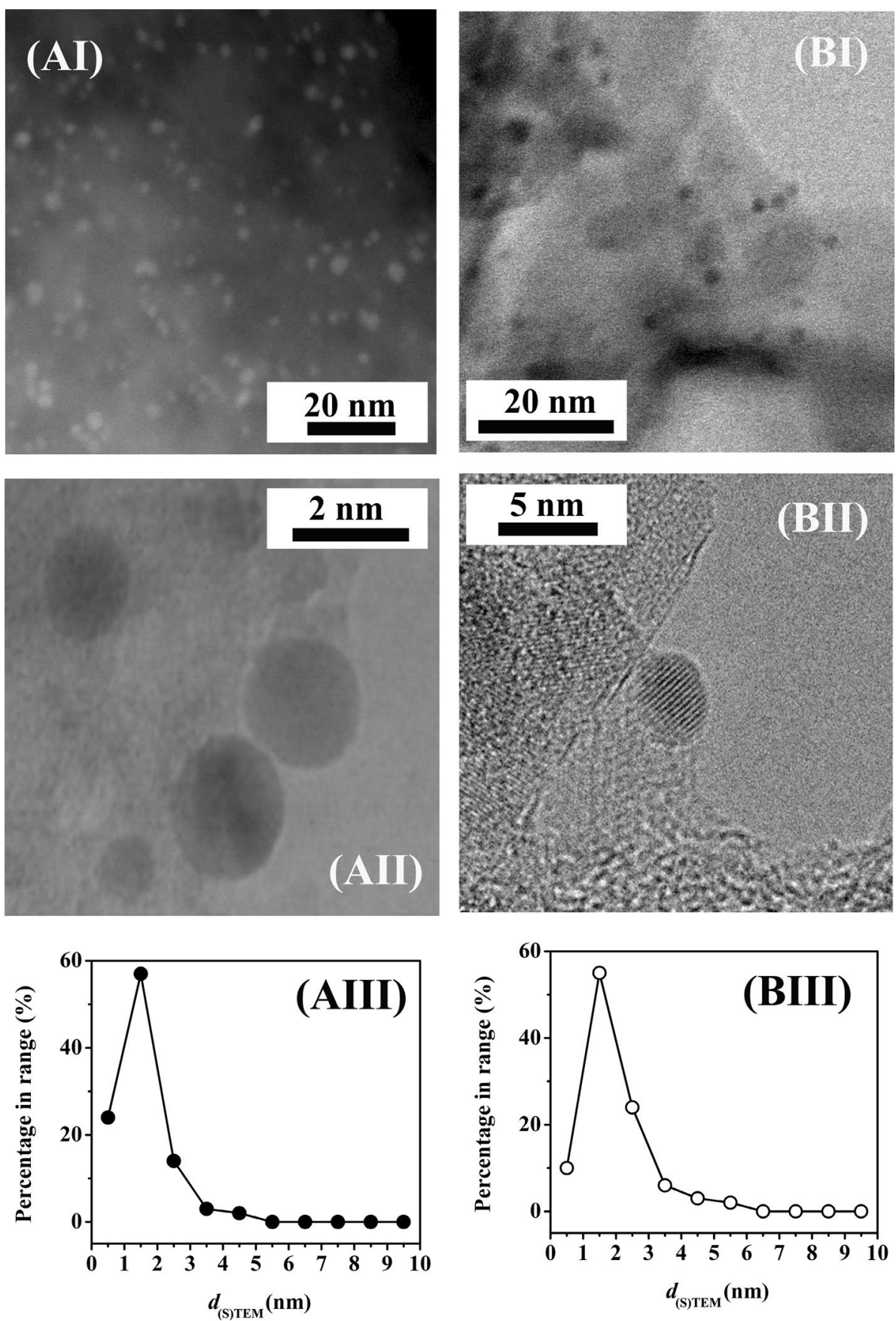
which can contribute to the observed higher DBA production rate over $\mathrm{Pd} / \mathrm{C}$.

As DBA formation involves hydrogenation of BBA (Fig. 1, step 3), availability of surface reactive hydrogen is an important parameter. Total surface hydrogen was evaluated by $\mathrm{H}_{2}$ TPD where in both cases $\mathrm{H}_{2}$ release far exceeded that measured in the chemisorption step (Table 1). This suggests hydrogen spillover, i.e. $\mathrm{H}_{2}$ dissociation at $\mathrm{Pd}$ sites with migration of atomic hydrogen to the support [39]. We can note studies that have established the occurrence of hydrogen spillover on activated carbon [40] and $\mathrm{Al}_{2} \mathrm{O}_{3}$ [41] supported Pd. Hydrogen desorption from $\mathrm{Pd} / \mathrm{C}$ was appreciably greater than $\mathrm{Pd} / \mathrm{Al}_{2} \mathrm{O}_{3}$ and can be linked to the higher SSA of Pd/C (Table 1), which can accommodate more spillover [40]. Reaction exclusivity was retained for the two catalysts over the temperature range $453 \leq T \leq 523 \mathrm{~K}$ and the associated Arrhenius plots are shown in Fig. 3. The resultant apparent activation energy $\left(79 \mathrm{~kJ} \mathrm{~mol}^{-1}\right)$ converged for both catalysts and is lower than that $\left(100 \mathrm{~kJ} \mathrm{~mol}^{-1}\right)$ reported for the conversion of monopentylamine to di-pentylamine [42]. The results establish that $\mathrm{Pd} / \mathrm{Al}_{2} \mathrm{O}_{3}$ and $\mathrm{Pd} / \mathrm{C}$ promote the gas phase continuous conversion of MBA solely to DBA. Pd/C delivered a higher DBA production rate, which can be associated with greater surface acidity (from $\mathrm{NH}_{3}$ chemisorption/TPD) that favours the condensation step and increased surface reactive hydrogen (from $\mathrm{H}_{2} \mathrm{TPD}$ ) that serves to promote BBA hydrogenation to DBA.

\subsection{Production of TBA from DBA}

Given full selectivity to DBA from MBA, we explored the feasibility of continuous TBA production from DBA as feed. The conversion of DBA over both Pd catalysts generated a mixture of MBA and TBA, which is in line with a patent that serves as the only documented report of tertiary amine formation from secondary amines [9]. In terms of activity, $\mathrm{Pd} / \mathrm{C}$ again delivered a significantly higher DBA consumption rate (Table 2). Selectivity was independent of

Table 1 Physico-chemical properties of $\mathrm{Pd} / \mathrm{C}$ and $\mathrm{Pd} / \mathrm{Al}_{2} \mathrm{O}_{3}$

\begin{tabular}{lll}
\hline Catalyst & $\mathrm{Pd} / \mathrm{C}$ & $\mathrm{Pd} / \mathrm{Al}_{2} \mathrm{O}_{3}$ \\
\hline$d_{(\mathrm{S}) \mathrm{TEM}}(\mathrm{nm})$ & 2.5 & 3.0 \\
$\mathrm{NH}_{3}$ chemisorbed $\left(10^{-5} \mathrm{~mol} \mathrm{~g}^{-1}\right)$ & 94 & 52 \\
$\mathrm{NH}_{3} \mathrm{TPD}\left(10^{-5} \mathrm{~mol} \mathrm{~g}^{-1}\right)$ & 92 & 51 \\
$\mathrm{H}_{2}$ chemisorbed $\left(10^{-2} \mathrm{~mol} \mathrm{~mol}_{\mathrm{Pd}}{ }^{-1}\right)$ & 27 & 22 \\
$\mathrm{H}_{2} \mathrm{TPD}\left(10^{-2} \mathrm{~mol} \mathrm{~mol}_{\mathrm{Pd}}{ }^{-1}\right)$ & 849 & 102 \\
$\mathrm{SSA}\left(\mathrm{m}^{2} \mathrm{~g}^{-1}\right)$ & 870 & 145 \\
$\mathrm{Pd} 3 d_{5 / 2} \mathrm{BE}(\mathrm{eV})$ & 335.9 & 334.9 \\
\hline
\end{tabular}

DBA conversion (Fig. 4) where $\mathrm{Pd} / \mathrm{C}$ generated equivalent amounts of TBA and MBA whereas $\mathrm{Pd} / \mathrm{Al}_{2} \mathrm{O}_{3}$ promoted preferential formation of TBA. Based on the product distributions, we propose the reaction mechanism presented in Fig. 5, which involves dehydrogenation (DBA $\rightarrow$ BBA, step I) and hydrogen mediated disproportionation (BBA + DBA $\rightarrow \mathrm{MBA}+\mathrm{TBA}$, step II). DBA adsorbs on Pd through the lone pair of electrons on $\mathrm{N}$ [43] resulting in bond polarisation $\left(\mathrm{N}^{\delta-}-\mathrm{C}^{\delta+}\right)$, leading to dehydrogenation and the formation of BBA. Baiker [44] has established (by FTIR) formation of $\mathrm{N}$-methylidene-methylamine from di-methylamine dehydrogenation (on $\mathrm{Cu}$ ). Disproportionation of BBA with DBA generates TBA with the release of MBA. Xu et al. [45] working with $\mathrm{CuO}-\mathrm{NiO}-\mathrm{PtO} / \gamma-\mathrm{Al}_{2} \mathrm{O}_{3}$ in gas phase operation under conditions similar to those used in this work (i.e. $473 \mathrm{~K}, 1 \mathrm{~atm}$ ) demonstrated the formation of an aliphatic amine mixture ( $N$-ethyl- $n$-butylamine, ethylamine, diethylamine, butylamine, dibutylamine and $N, N$-diethylbutylamine) via disproportionation of ethylamine + butylamine in hydrogen. Formation of TBA as product follows steps I/II in Fig. 5. The MBA that is generated can undergo combined dehydrogenation/condensation/ hydrogenation as shown in Fig. 1 to form DBA. The catalytic results suggest that reaction over $\mathrm{Pd} / \mathrm{C}$ predominantly follows steps I/II with equi-molar production of TBA and MBA. MBA formed on $\mathrm{Pd} / \mathrm{Al}_{2} \mathrm{O}_{3}$ must undergo reaction (to generate DBA) with an overall greater relative enrichment of TBA in the product stream.

Amine activation is governed by the electronic properties of the metal phase [46] that are, in turn, influenced by interactions with the carrier [32]. XPS analysis was conducted over the $\mathrm{Pd} 3 d$ binding energy (BE) range in order to establish Pd charge and the resultant profiles are presented in Fig. 6; $\mathrm{BE}$ values are given in Table $1 . \mathrm{Pd} / \mathrm{C}$ (Fig. 6A) exhibited a $\mathrm{Pd}$ $3 d_{5 / 2}$ signal (at $335.9 \mathrm{eV}$ ) that is $0.7 \mathrm{eV}$ higher than metallic $\mathrm{Pd}(335.2 \mathrm{eV})$ [47] indicating electron transfer to the carbon

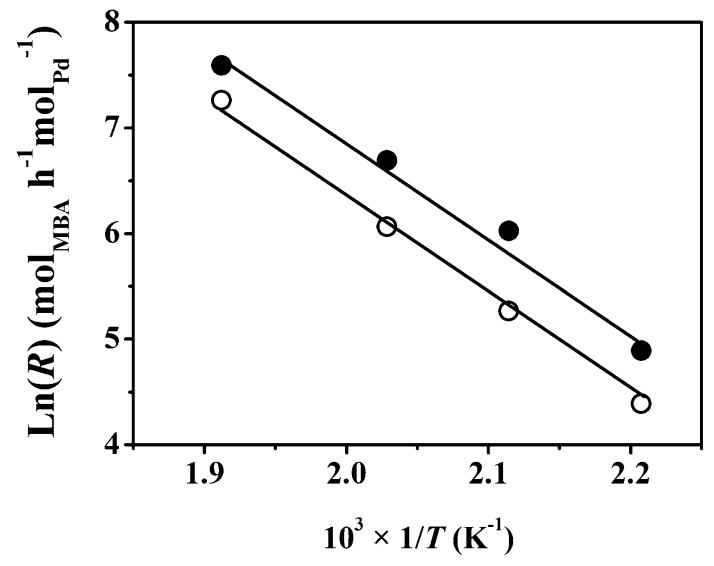

Fig. 3 Arrhenius plots for the conversion of mono-butylamine (MBA) to di-butylamine (DBA) over $\mathrm{Pd} / \mathrm{C}$ (filled circle) and $\mathrm{Pd} /$ $\mathrm{Al}_{2} \mathrm{O}_{3}$ (open circle) 


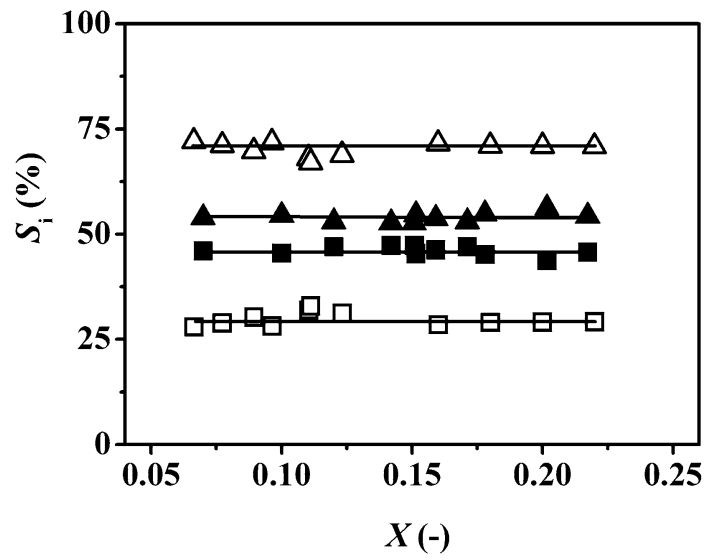

Fig. 4 Selectivity $\left(S_{\mathrm{i}}, \%\right)$ to mono-butylamine [MBA (filled square, open square)] and tri-butylamine [TBA (filled triangle, open trian$g l e)]$ as a function of di-butylamine (DBA) fractional conversion $(X)$ for reaction over $\mathrm{Pd} / \mathrm{C}$ (solid symbols) and $\mathrm{Pd} / \mathrm{Al}_{2} \mathrm{O}_{3}$ (open symbols); $T=473 \mathrm{~K} ; P=1 \mathrm{~atm}$

support with the generation of $\mathrm{Pd}^{\delta+}$, as proposed elsewhere for nano-scale $(4-12 \mathrm{~nm}) \mathrm{Pd}$ on carbon [32, 48]. In contrast, $\mathrm{Pd} / \mathrm{Al}_{2} \mathrm{O}_{3}$ (Fig. 6B) is characterised by a $\mathrm{Pd} 3 d_{5 / 2} \mathrm{BE}$ $(334.9 \mathrm{eV})$ that is $0.3 \mathrm{eV}$ lower than the metallic Pd reference, suggesting (partial) support $\rightarrow$ metal electron transfer. This is in accordance with the reported occurrence of electron-rich $\mathrm{Pd}^{\delta-}(2-10 \mathrm{~nm})$ on $\mathrm{Al}_{2} \mathrm{O}_{3}$ [32]. The nitrogen in DBA bearing two electron-donating $n$-butyl chains is more electron-rich than in MBA [49] with a consequent stronger interaction with $\mathrm{Pd}^{\delta+}$ sites on the carbon support and competition for adsorption sites must result in a displacement of MBA from the surface by DBA. On the other hand, $\mathrm{Pd}^{\delta-}$ sites on $\mathrm{Al}_{2} \mathrm{O}_{3}$ exhibit greater repulsion with respect to DBA relative to MBA where the latter is not displaced from the surface and can be transformed to DBA (Fig. 1). Monitoring the $\mathrm{pH}$ of an aqueous trap downstream of the reactor demonstrated greater alkalinity of the exhaust stream for reaction over $\mathrm{Pd} /$ $\mathrm{Al}_{2} \mathrm{O}_{3}(\mathrm{pH}=9.5)$ compared with $\mathrm{Pd} / \mathrm{C}(\mathrm{pH}=7.8)$, which is consistent with $\mathrm{NH}_{3}$ production over the former via step 2 in Fig. 1.

In the proposed reaction scheme, surface reaction of DBA with BBA (step (II) in Fig. 5) results in TBA and MBA production. Operation of a second catalyst bed in series should facilitate conversion of MBA (to DBA) exiting the first bed leading to increased TBA yield. The experimental results obtained are provided in Table 2 where the same total mass

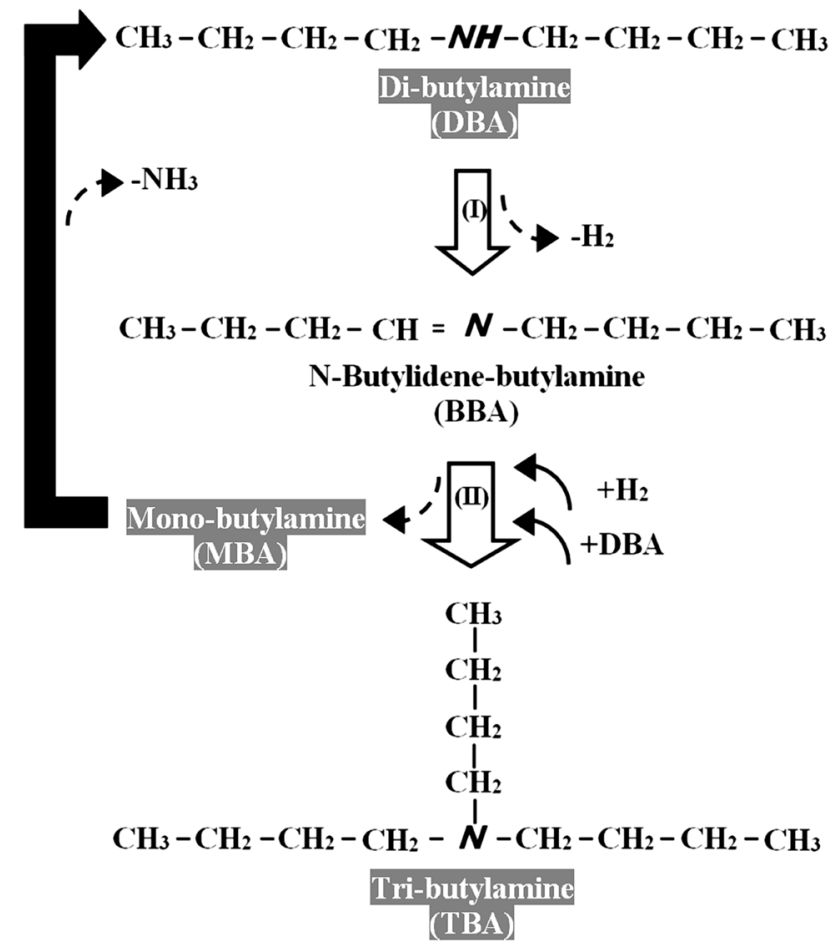

Fig. 5 Proposed reaction scheme for the transformation of di-butylamine (DBA)

of catalyst was divided into $\mathrm{N}(=1-3)$ beds at the same inlet DBA and $\mathrm{H}_{2}$ flow rate. An increase in overall reaction rate and TBA selectivity was observed with increasing number of beds to attain target tertiary amine exclusivity in a two-bed arrangement for $\mathrm{Pd} / \mathrm{Al}_{2} \mathrm{O}_{3}$ and triple $\mathrm{Pd} / \mathrm{C}$ bed. This is the first time that full selectivity to a tertiary amine from a secondary amine feedstock has been reported. The higher TBA selectivity achieved over $\mathrm{Pd} / \mathrm{Al}_{2} \mathrm{O}_{3}$ relative to $\mathrm{Pd} / \mathrm{C}$ (Fig. 4) translated into a requisite lower number of catalyst beds in series to achieve full TBA selectivity.

\section{Conclusions}

We have established exclusive formation of higher amines (DBA and TBA) from a lower amine (MBA and DBA, respectively) feedstock over nano-scale Pd (mean size $=2.5-3.0$ ) supported on $\mathrm{C}$ and $\mathrm{Al}_{2} \mathrm{O}_{3}$ in gas phase continuous operation. Full selectivity in the conversion of MBA to DBA was attained over both catalysts with an associated apparent activation energy $=79 \mathrm{~kJ} \mathrm{~mol}^{-1}$.
Table 2 Di-butylamine (DBA) consumption rate $(R)$ and selectivity to tri-butylamine $\left(S_{\mathrm{TBA}}\right)$ in single-, double- and triple- $\mathrm{Pd} / \mathrm{Al}_{2} \mathrm{O}_{3}$ and $\mathrm{Pd} / \mathrm{C}$ $\operatorname{bed}(\mathrm{s}) ; P=1 \mathrm{~atm}, T=473 \mathrm{~K}$

\begin{tabular}{llllll}
\hline Catalyst & $\mathrm{Pd} / \mathrm{C}$ & & $\mathrm{Pd} / \mathrm{Al}_{2} \mathrm{O}_{3}$ & \\
\cline { 2 - 3 } \cline { 5 - 6 } & $R\left(\mathrm{~mol}_{\mathrm{DBA}} \mathrm{h}^{-1} \mathrm{~mol}_{\mathrm{Pd}}{ }^{-1}\right)$ & $S_{\mathrm{TBA}}(\%)$ & & $R\left(\mathrm{~mol}_{\mathrm{DBA}} \mathrm{h}^{-1} \mathrm{~mol}_{\mathrm{Pd}}{ }^{-1}\right)$ & $S_{\mathrm{TBA}}(\%)$ \\
\hline Single-bed & 489 & 52 & & 34 & 70 \\
Double-bed & 622 & 92 & & 43 & 100 \\
Triple-bed & 698 & 100 & & - & - \\
\hline
\end{tabular}




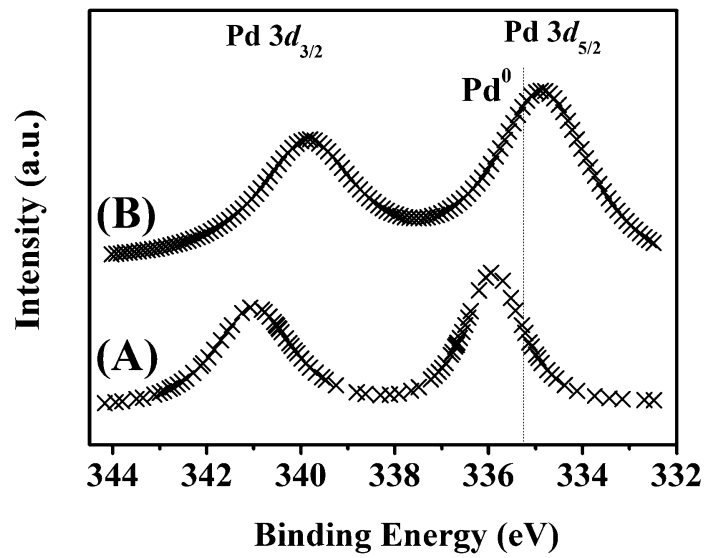

Fig. 6 XPS spectra over the Pd $3 d$ binding energy (BE) region recorded for $\boldsymbol{A} \mathrm{Pd} / \mathrm{C}$ and $\boldsymbol{B} \mathrm{Pd} / \mathrm{Al}_{2} \mathrm{O}_{3}$

Reaction over Pd/C delivered a significantly higher DBA production rate, which is explained on the basis of a higher level of surface acidity (from $\mathrm{NH}_{3}$ chemisorption/TPD) and spillover hydrogen (from $\mathrm{H}_{2}$ TPD). Exclusive formation of TBA (from DBA) has been achieved over both catalysts where operation of beds in series resulted in higher TBA production rates. A reaction mechanism is proposed that accounts for our experimental observations. The results from this work can serve as a basis for an alternative clean and continuous production of higher amines from a lower amine feedstock.

Acknowledgements We acknowledge Dr. M. Li and Dr. X. Wang for their contribution to this work, EPSRC support for free access to the TEM/SEM facilities at the University of St. Andrews and financial support to Y. Hao through the Overseas Research Students Award Scheme (ORSAS).

Open Access This article is distributed under the terms of the Creative Commons Attribution 4.0 International License (http:// creativecommons.org/licenses/by/4.0/), which permits unrestricted use, distribution, and reproduction in any medium, provided you give appropriate credit to the original author(s) and the source, provide a link to the Creative Commons license, and indicate if changes were made.

\section{References}

1. He W, Wang L, Sun C, Wu K, He S, Chen J, Wu P, Yu Z (2011) Chem A Eur J 17:13308

2. Wang X, Liu S, Yu T, Chai Y (2014) Eur Chem Bull 3:55

3. Salvatore RN, Yoon CH, Jung KW (2001) Tetrahedron 57:7785

4. Dang TT, Ramalingam B, Shan SP, Seayad AM (2013) ACS Catal 3:2536

5. He L, Qian Y, Ding R-S, Liu Y-M, He H-Y, Fan K-N, Cao Y (2012) ChemSusChem 5:621

6. Huang Y, Sachtler WMH (1999) J Catal 188:215

7. Arai M, Takada Y, Nishiyama Y (1998) J Phys Chem B 102:1968
8. Iwasa N, Yoshikawa M, Arai M (2002) Phys Chem Chem Phys $4: 5414$

9. Fenton DM (1973) Preparation of Trialkylamines. US Patent 3,726,925, Apr. 10.

10. Kamiguchi S, Ikeda N, Nagashima S, Kurokawa H, Miura H, Chihara T (2009) J Clust Sci 20:683

11. The-Kai B, Concilio C, Porzi G (1981) J Org Chem 208:249

12. Murahashi S, Yoshimura N, Tsumiyama T, Kojima T (1983) J Am Chem Soc 105:5002

13. Yamashita M, Moroe Y, Yano T, Nozaki K (2011) Inorg Chim Acta 369:15

14. Lorentz-Petersen LLR, Jensen P, Madsen R (2009) SynthStuttgart 24:4110

15. Miyazawa A, Saitou K, Tanaka K, Gädda TM, Tashiro M, Prakash GKS, Olah GA (2006) Tetrahedron Lett 47:1437

16. Kim I, Itagaki S, Jin XJ, Yamaguchi K, Mizuno N (2013) Catal Sci Technol 3:2397

17. Izawa Y, Pun D, Stahl SS (2011) Science 333:209

18. Rodríguez L, Romero D, Rodríguez D, Sánchez J, Domínguez F, Arteaga G (2010) Appl Catal A Gen 373:66

19. Sobota M, Nikiforidis I, Amende M, Zanón BS, Staudt T, Höfert O, Lykhach Y, Papp C, Hieringer W, Laurin M, Assenbaum D, Wasserscheid P, Steinrück H-P, Görling A, Libuda J (2011) Chem A Eur J 17:11542

20. Blaser H-U, Indolese A, Schnyder A, Steiner H, Studer M (2001) J Mol Catal A Chem 173:3

21. Yap AJ, Masters AF, Maschmeyer T (2012) ChemCatChem 4:1179

22. Armbrüster M, Behrens M, Cinquini F, Föttinger K, Grin Y, Haghofer A, Klötzer B, Knop-Gericke A, Lorenz H, Ota A, Penner S, Prinz J, Rameshan C, Révay Z, Rosenthal D, Rupprechter N, Sautet P, Schlögl R, Shao L, Szentmiklósi L, Teschner D, Torres D, Wagner R, Widmer R, Wowsnick G (2012) ChemCatChem 4:1048

23. Amorim C, Keane MA (2008) J Chem Technol Biotechnol 83:662

24. Rodríguez-Reinoso F (1998) Carbon 36:159

25. Kim S, Byl O, Yates JT (2005) J Phys Chem B 109:6331

26. Ortiz-Hernandez I, Williams CT (2007) Langmuir 23:3172

27. Strunk MR, Williams CT (2003) Langmuir 19:9210

28. Braos-García P, Maireles-Torres P, Rodríguez-Castellón E, Jiménez-López A (2003) J Mol Catal A Chem 193:185

29. Verhaak MJFM, Dillen AJv, Geus JW (1994) Catal Lett 26:37

30. Landge SM, Atanassova V, Thimmaiah M, Török B (2007) Tetrahedron Lett 48:5161

31. Atanassova V, Ganno K, Kulkarni A, Landge SM, Curtis S, Foster M, Török B (2011) Appl Clay Sci 53:220

32. Cárdenas-Lizana F, Hao Y, Crespo-Quesada M, Yuranov I, Wang X, Keane MA, Kiwi-Minsker L (2013) ACS Catal 3:1386

33. Ayers GP, Gillett RW, Caeser ER (1985) Tellus B 37:35

34. Gómez-Quero S, Cárdenas-Lizana F, Keane MA (2008) Ind Eng Chem Res 47:6841

35. Braos-García P, Maireles-Torres P, Rodríguez-Castellón E, Jiménez-López A (2001) J Mol Catal A Chem 168:279

36. Wilson OM, Knecht MR, Garcia-Martinez JC, Crooks RM (2006) J Am Ceram Soc 128:4510

37. Sotoodeh F, Smith KJ (2011) J Catal 279:36

38. Hao Y, Wang X, Perret N, Cárdenas-Lizana F, Keane MA (2015) Catal Struct React 1:4

39. Prins R (2012) Chem Rev 112:2714

40. Amorim C, Keane MA (2008) J Colloid Interf Sci 322:196

41. Conner WC, Falconer JL (1995) Chem Rev 95:759

42. Sonnemans J, Mars P (1974) J Catal 34:215

43. Wokaun A, Baiker A, Miller SK, Fluhr W (1985) J Phys Chem $89: 1910$ 
44. Baiker A (1993) Catalytic amination of alcohols and its potential for the synthesis of amines. In: Kosak JR, Johnson TA (eds) Catalysis of organic reactions. Marcel Dekker, New York,pp 91-102

45. Xu LF, Huang JM, Qian C, Chen XZ, Feng L, Chen YB, He CH (2013) Res Chem Intermed 39:2697

46. Hao Y, Li M, Cárdenas-Lizana F, Keane MA (2016) Catal Lett 146:109
47. Brun M, Berthet A, Bertolini JC (1999) J Electron Spectrosc 104:55

48. Jiang L, Gu H, Xu X, Yan X (2009) J Mol Catal A Chem 310:144

49. Lawrence SA (2004) Amines: synthesis, properties and applications, vol 1. Cambridge University Press, Cambridge 